\title{
Alterations in the morphology and motility of spermatozoa: relation with total sperm count
}

\author{
Sperm morfoloji ve motilitesindeki değişikliklerin toplam sperm sayısı ile ilişkisi
}

\author{
Aysun Karabulut*, Arzu Tekin** \\ * Pamukkale Üniversitesi, Tıp Fakültesi, Kadın Hastalıkları ve Doğum AD, Denizli \\ ** Denizli Devlet Hastanesi, Infertilite Kliniği, Denizli
}

\begin{abstract}
Purpose: The aim of this study was to investigate the differences in sperm morphology and motility in patients with different sperm counts, and to search the influence of sperm morphology over sperm motility.

Materials and methods: We evaluated semen analysis of 1174 males admitted to infertility clinic using "Makler counting camber" for evaluation of number and motility, and strict criteria (Kruger-Tyberg) for the morphological assessment. According to total sperm count, patients were divided into three groups; group I $(n=119)$ had $<5 \times 10^{6} / \mathrm{mL}$, group II $(\mathrm{n}=125)$ had $5-15 \times 10^{6} / \mathrm{mL}$, and group III $(\mathrm{n}=930)$ had $\geq 15 \times 10^{6} / \mathrm{mL}$ total sperm count. The groups were compared in terms of motility, morphology and the distribution of sperm abnormalities.

Results: Sperm motility was significantly lower in groups I-II compared to group III $(p<0.01)$. In the semen analysis, normal sperm morphology above $4 \%$ was detected in $7.1 \%$ of group II, $17.5 \%$ of group III, and none in group I $(p<0.01)$. Significantly less tail defects were detected in group III compared to others $(p<0.01)$. Progressive sperm motility significantly correlated with morphology $(r=0.38, p<0.001)$. Among morphologic abnormalities, tail problems were highly correlated with nonmotile sperm count $(r=0.30, p<0.001)$. Tail defects correlated positively with midpiece $(r=0.24, p<0.001)$, and negatively with head defects $(r=-0.71, p<0.001)$. Normal sperm morphology had a negative relation with tail and midpiece defects $(r=-0.20, p<0.001$ and $r=-0.30$, $p<0.001$ respectively).

Conclusion: Sperm motility and morphology were deteriorated with the decreasing sperm count in subfertile population. The chance of finding normal morphology above the critical value of $4 \%$ diminishes in cases with sperm counts less than $5 \times 10^{6} / \mathrm{mL}$. Therefore, it is logical to canalize these patients directly to assisted reproductive technologies.
\end{abstract}

Pam Med J 2013;6(1):1-4

Key words: Spermatozoa, infertility, progressive sperm motility, Kruger criteria

Özet

Amaç: Bu çalışmada farklı sperm sayılarına sahip erkeklerde sperm morfoloji ve motilite düzeylerini araştırmayı ve bu parametrelerin total sperm sayısı ile korelasyonunu incelemeyi amaçladık.

Gereç ve yöntem: İnfertilite ünitesine başvuran 1174 erkeğin semen parametreleri "Makler sayım kamarası" kullanılarak incelendi. Morfolojik değerlendirme için strikt kriter (Kruger-Tyberg) kullanıldı. Total sperm sayısına göre hastalar üç gruba ayrıldı; grup I $(n=119)<5$ milyon $/ \mathrm{mL}$, grup II $(n=125) 5-15 \times 10^{6} / \mathrm{mL}$, ve group III $(n=930)$ $\geq 15 \times 10^{6} / \mathrm{mL}$ total sperm sayısına sahipti. Gruplar motilite, morfoloji ve yapısal sperm anormallikleri açısından karşılaştırıldı.

Bulgular: Grup IIl'e gore, grup I ve Il'de sperm motilitesi anlamlı olarak daha düşüktü $(p<0.01)$. Semen örneğinde normal sperm morfolojisinin \% 4 veya üzerinde olan vakalar grup II de \%7.1, grup IIl'de \%17.5 iken grup l'de tüm örneklerde <\%4 idi ( $p<0.01)$. Grup III'de kuyruk defekti oranı anlamlı olrak daha düşüktü $(p<0.01)$. Progressif sperm motilitesi ile sperm morfolojisi arasında anlamlı korelasyon mevcuttu $(r=0.38, p<0.001)$. Morfolojik anormallikler arasında kuyruk problemleri ile en yakın korelasyon gösteren parametre nonmotil sperm sayısı idi $(r=0.30, p<0.001)$. Kuyruk problemleri boyun defektleri ile pozitif $(r=0.24, p<0.001)$, baş defektleri ile negatif korelasyon gösteriyordu $(r=-0.71, p<0.001)$. Normal sperm morfolojisi kuyruk ve boyun defektleri ile negatif korelasyon gösteriyordu ( $r=-0.20, p<0.001$ and $r=-0.30, p<0.001$ respectively).

Sonuç: Subfertil populasyonda azalan sperm sayısı ile birlikte hem sperm motilitesi hem de sperm morfolojisinde bozulma izlenmektedir. Sperm sayısının $<5 \times 10^{6} / \mathrm{mL}$ olduğu vakalarda, normal morfolojide sperm bulma olasılığı azaldığından, bu grup hastaların doğrudan yardımcı üreme tekniklerine yönlendirilmesi uygun olacaktır.

Pam Tıp Derg 2013;6(1):1-4

Anahtar sözcükler: Spermatozoa, infertilite, ileri hareketli sperm sayısı, sperm motilitesi, Kruger kriteri

Aysun Karabulut

Yazışma Adresi: Pamukkale Üniversitesi, Tıp Fakültesi, Kadın Hastalıkları ve Doğum AD, Denizli

e-mail: aysunkarabulut@yahoo.com

Gönderilme tarihi: 23.10.2012

Kabul tarihi: 13.11 .2012 


\section{Introduction}

Sperm count, as well as semen quality, plays a major role in the management of infertile couple and the success of treatment. Although sperm count is in normal limits, the same may not be true for the semen quality. Sperm morphology, besides motile sperm count, is a major component of sperm analysis and has been considered as a good indicator of semen quality [1]. A high rate of morphologic abnormality in the ejaculate has been correlated with lowered fertility [2-6]. The morphology and motility may be related to sperm survival and ability to fertilize the ovum $[7,8]$. We hypothesized that the morphology and motility of spermatozoa in semen analysis are interrelated with each other and with total sperm count in the ejaculate. In this study, we aimed to investigate the alterations in sperm morphology and motility in patients with different sperm counts, and to search the influence of sperm morphology over sperm motility.

\section{Materials and methods}

Semen analysis of male partners of couples admitted for the infertility was evaluated. We evaluated a total of 1174 semen analysis of patients admitted to Infertility unit of Denizli State Hospital, Denizli, Turkey. Immediately after collection, the sperm quality of each ejaculate (volume, sperm concentration, sperm motility, and normal morphology) was microscopically evaluated by standard laboratory techniques. The ejaculates were placed in an incubator at $37{ }^{\circ} \mathrm{C}$ during analysis of seminal parameters. Sperm concentration in each ejaculate was determined by "Makler counting chamber" (Irvine Scientific, Santa Ana, CA, USA) using OLYMPUS Bx51phase contrast microscopy (x200) (OLYMPUS life science Europa GMBH, Hamburg, Germany). For the accuracy of the testing, two samplings were carried out from each case. Four places with 10 square were counted (totally 40 squares). Progressive individual motility scores were subjectively assessed. Sperm motility was classified as nonmotile, nonprogressively motile, and progressively motile according to type of motility. Coefficiency of variation was detected less than $5 \%$. In low sperm counts, 100 squares were counted.

Morphologic evaluation was performed via Diff Quick staining (Reastain Quick-Diff Kit ${ }^{\circledR}$, Reagena International Oy Ltd, Toivala, Finland) under a magnification of $\times 1000$ with immersion oil. Classification was performed according to Tygerberg Kruger criteria [9].
Three groups were formed according to total sperm count per milliliter $(\mathrm{mL})$; patients in group I had $<5 \times 10^{6}$ sperms $/ \mathrm{mL}$, group II had $5-15 \times 10^{6} / \mathrm{mL}$, and group III $\geq 15 \times 10^{6} / \mathrm{mL}$, total sperm count. The groups were compared for the percentage of motility, Kruger morphology and the distribution of sperm abnormalities.

Statistical analysis was performed using statistical package for social sciences (SPSS 10.0, Chicago, IL) software. Continuous variables were expressed as mean \pm standard deviation (SD). Kolmogorov Simirnov-Z test was used to analyze distribution of investigated parameters. One way Anova test was used for the analysis of continuous variables showing normal distribution. For the variables not showing normal distribution, Kruskall Wallis test was used. Spearman correlation test was performed to analyze the relationship between progressive motility, nonprogressive motile sperms and nonmotile sperms, Kruger morphology and morphologic abnormalities. Statistical significance was defined as p-value less than 0.05 .

\section{Results}

Out of 1174 semen analysis included into the study, $930(79.2 \%)$ patients had $\geq 15 \times 10^{6}$

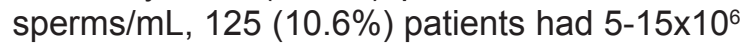
sperms $/ \mathrm{mL}$, and $119(10.2 \%)$ patients had $<5 \times 10^{6} \mathrm{sperms} / \mathrm{mL}$. There was no difference for the mean age among groups (31.8 \pm 7.4 ; $30.8 \pm 5.3$ and $30.7 \pm 6.1$ years for groups I, II and III respectively, $p>0.05)$. Characteristics of the semen analysis of each group are shown in Table 1. There was no difference for head and midpiece abnormality among groups. However, a significant difference was detected between each group for the progressive sperm motility $(p<0.01)$. While there was no difference for the nonprogressive motility and nonmotile sperm percentile between groups I and II, a significant difference was observed between groups II and III, and groups I and III ( $p<0.01)$. In group I, there was no spermiogram with normal morphology above $4 \%$ according to Kruger criteria. On the other hand, normal morphology above $4 \%$ was achieved in $7.1 \%$ of group II and $17.5 \%$ of group III $(p<0.01)$. Regarding the normal morphology and tail defects, significant difference was detected only between groups II-III and groups I-III $(p<0.01)$. Progressive sperm motility significantly correlated with normal morphology $(r=0.38, p<0.001)$. A negative correlation was detected between nonmotile sperm count and normal morphology ( $r=-373, p<0.001)$. Among morphologic abnormalities, tail problems 
Table 1. Comparison of semen quality in subjects with different sperm count per milliliter

\begin{tabular}{|c|c|c|c|c|}
\hline & $\begin{array}{l}\text { Group I } \\
(n=119)\end{array}$ & $\begin{array}{l}\text { Group II } \\
(n=125)\end{array}$ & $\begin{array}{l}\text { Group III } \\
(n=930)\end{array}$ & $P$ value \\
\hline Age $(\text { years) })^{\star}$ & $31.8 \pm 7.4$ & $30.8 \pm 5.3$ & $30.7 \pm 6.1$ & NS \\
\hline Sperm count (million/mL) $)^{*}$ & $1.8 \pm 2.1$ & $10.3 \pm 9.3$ & $51.9 \pm 2.6$ & \\
\hline Progresive motility $(\%)^{* *}$ & $3(9)$ & $7(11)$ & $13(5)$ & $\begin{array}{l}\text { Group I-II; } p=0.02 \text { group } \\
\text { II-III and I-III; } p<0.001\end{array}$ \\
\hline Nonprogressive & $27(12)$ & $32(18)$ & $32(18)$ & $\begin{array}{l}\text { Group I-III; } p<0.001 \text { group } \\
\text { II-III; } p=0.003\end{array}$ \\
\hline Motility $(\%)^{* *}$ & & & & \\
\hline Nonmotile sperm $(\%)^{\star *}$ & $53(32)$ & $47(24)$ & $47(24)$ & $\begin{array}{l}\text { Group I-III and II-III; } \\
p<0.001\end{array}$ \\
\hline Kruger morphology $(\%)^{\star *}$ & $1(1)$ & $2(2)$ & $3(2)$ & $\begin{array}{l}\text { Group I-III and II-III; } \\
p=0.003\end{array}$ \\
\hline Head abnormality $(\%)^{* *}$ & $83(6)$ & $83(5)$ & $83(6)$ & NS \\
\hline Midpiece abnormality $(\%)^{\star \star}$ & $8(5)$ & $8(4)$ & $8(4)$ & NS \\
\hline Tail abnormality $(\%)^{* *}$ & $6(5)$ & $6(4)$ & $5(4)$ & $\begin{array}{l}\text { Group II-III; } p=0.003 \text {, group } \\
\text { I-III; } p=0.029\end{array}$ \\
\hline
\end{tabular}

were highly correlated with nonmotile sperm count $(r=0.30, p<0.001)$. Although there was a positive relation between midpiece and tail defects $(r=0.24, p<0.001)$, there was a negative correlation between head and tail defects $(r=-0.71, p<0.001)$. For the percentage of normal morphology, no correlation was detected with head problems, however there was a negative relation with tail and midpiece defects $(r=-0.20$, $p<0.001$ and $r=-0.30, p<0.001$ respectively).

\section{Discussion}

In the present study, semen analysis of 1174 patients were evaluated for motility and morphology. Sperm parameters have been correlated with success in intrauterine insemination and in vitro fertilization procedures. Sperm morphology is one of the best indicators of male infertility [10]. The main problem with the use of morphology is the subjective nature of this parameter. In this study, we used Tygerberg "strict" criteria (Kruger criteria), most commonly used classification system, to classify sperm morphology $[9,11]$. In metaanalysis of studies for predictive value of normal sperm morphology in intrauterine insemination, a significant improvement in pregnancy rate was shown above $4 \%$ according to strict criteria [12]. In our study, we did not detect any spermiogram above this cut off in patient with sperm counts $<5 \times 10^{6}$ sperms $/ \mathrm{mL}$. Progressive sperm motility was also significantly lower in this group compared to others. The current data concur with the previous studies indicating questionable IUI success in patients with sperm counts less than $5 \times 10^{6}$ sperm $/ \mathrm{mL}$. This group of patients formed the $9.5 \%$ of our infertile population. In previous studies, the cutoff value above which IUI seems to be more successful, varies between $0.25-5 \times 10^{6}$ sperms/ $\mathrm{mL}$ [13-15]. Ombelet et al emphasized the importance of morphology especially in cases with inseminating sperm counts below $1 \times 10^{6} / \mathrm{mL}$ and the authors implied low success rates in this group of patients [12]. Different from our study, they used inseminating sperm counts in their study. In all of sperm parameters, it was shown that progressive sperm motility and normal Kruger morphology were higher in patients with higher total sperm count per $\mathrm{mL}$ [12]. Sperms with abnormal morphology were shown to be less motile. In this study, sperm values less than 15 million per $\mathrm{mL}$ was seem to be critical for the strict morphology and further, we detected no cases with normal morphology above $4 \%$ in cases with sperm counts below $5 \times 10^{6}$ per $\mathrm{mL}$. Therefore, patients with sperm counts less than $5 \times 10^{6}$ per $\mathrm{mL}$ form the poor prognosis group for the IUI, and can be directed to reproductive technologies directly to be assisted. 
Progressive sperm motility was also decreasing with decreasing sperm counts. While progressive and nonprogressive motile sperm percentage decreases, nonmotile sperm percentage increases under the sperm values of less than 15 million per $\mathrm{mL}$. Although head and midpiece abnormalities do not change between groups, tail abnormalities inversely correlate with sperm count. Aydos et al detected deterioration of sperm morphology in all parts including tail, midpiece and head with suppressed sperm counts [16]. On the contrary, we only detected relation with tail abnormalities. We did not detect any difference between groups for head and midpiece abnormality. Therefore, tail abnormalities seem to be more determining factor in low sperm counts.

The major limitation of this study was the use of direct semen analysis. The same study may be performed after sperm washing and it may give more precise results. However, this study is important to highlight the importance of first step semen analysis in evaluation of couples.

In conclusion, both sperm motility and morphology are further deteriorated with the decreasing sperm count in subfertile population. The chance of finding normal morphology above the critical value of $4 \%$ diminishes in cases with sperm counts less than $5 \times 10^{6} / \mathrm{mL}$. Therefore, it is logical to canalize these patients directly to assisted reproductive technologies.

This study was exhibited as poster presentation in ESHRE, 1-4 July 2012, Istanbul, Turkey.

Conflict of interest: The authors declared no conflict of interest.

\section{References}

1. Rodriguez-Martinez H. Laboratory semen assessment and prediction of fertility: still utopia? Reprod Domest Anim 2003;38:312-318.

2. Bostofte E, Serup J, Rebbe H. Relation between morphologically abnormal spermatozoa and pregnancies obtained during a twenty-year follow-up period. Int J Androl 1982;5:379-386.

3. Carrell DT, Zobell RL, Middleton RG, Urry RL. A functional analysis and the potential clinical significance of 7 categories of sperm morphology. J Urol 1994;151:376-380.
4. Kruger TF, Acosta AA, Simmons KF, Swanson RJ, Matta JF, Oehninger S. Predictive value of abnormal sperm morphology in in vitro fertilization. Fertil Steril 1988;49:112-117.

5. Leroy-Martin B, Tanguy B, Lorthioir M, Soulez B, Hermand E. Analysis of the results obtained in fertilization in vitro according to the degree and type of teratospermia. J Gynecol Obstet Biol Reprod (Paris) 1994;23:373-377.

6. Oettle EE. Sperm morphology and fertility in the dog. J Reprod Fertil Suppl 1993;47:257-260.

7. Gil MC, García-Herreros M, Barón FJ, Aparicio IM, Santos AJ, García-Marín LJ. Morphometry of porcine spermatozoa and its functional significance in relation with the motility parameters in fresh semen. Theriogenology 2009;71:254-263.

8. Pena FJ, Saravia F, Garcia-Herreros M, Nunezmartinez I, Tapia JA, Johannisson A, Wallgren $\mathrm{M}$, Rodriguez-Martinez $\mathrm{H}$. Identification of sperm morphometric subpopulations in two different portions of the boar ejaculate and its relation to postthaw quality. J Androl 2005;26:716 -723.

9. World Health Organization, WHO laboratory manual for the examination and processing of human sperm. Fifth edition 2010.

10. Coetzee K, Kruge TF, Lombard CJ. Predictive value of normal sperm morphology: a structured literature review. Hum Reprod Update 1998;4:73-82.

11. Kruger TF, Acosta AA, Simmons KF, Swanson RJ, Matta JF, Oehninger S. Predictive value of abnormal sperm morphology in in vitro fertilization. Fertil Steril 1988;49:112-117.

12. Van Waart J, Kruger TF, Lombard CJ, Ombelet W. Predictive value of normal sperm morphology in intrauterine insemination (IUI): a structured literature review. Hum Reprod Update 2001;7:495-500.

13. Horvath PM, Bohrer M, Shelden RM, Kemmann E.The relationship of sperm parameters to cycle fecundity in superovulated women undergoing intrauterine insemination. Fertil Steril 1989;52:288-294.

14. Dodson WC, Haney AF.Controlled ovarian hyperstimulation and intrauterine insemination for treatment of infertility. Fertil Steril 1991;55:457-467.

15. Huang HY, Lee CL, Lai YM, Chang MY, Wang HS, Chang SY, Soong YK.The impact of the total motile sperm count on the success of intrauterine insemination with husband's spermatozoa. J Assist Reprod Genet 1996;13:56-63.

16. Aydos K, Ünlü C, Demirel C. Relation of the morphological alterations of spermatozoa with motility. J Turkish-German Gynecol Assoc 2000;1:5-8. 